\title{
EVALUATION OF SUBSTRATES MINERALIZATION BY C-CO2 FLUX UNDER NITROGEN FERTILIZATION
}

Víctor Manuel Montoya-Jasso ${ }^{\circledR} \bigotimes$, Gerardo Sergio Benedicto Valdés ${ }^{1}$, Víctor Manuel Ordaz-Chaparro ${ }^{1}$, Alejandrina Ruiz-Bello ${ }^{1}$, Jesús Manuel Arreola-Tostado ${ }^{2}$ and Ximena Castillo-Valdez ${ }^{1}$.

\begin{abstract}
${ }^{1}$ Colegio de Postgraduados. Road Mexico-Texcoco $\mathrm{Km}$. 36.5. Montecillo, Texcoco, State of Mexico, Mexico. CP 56230. montoya.victor@colpos.mx
\end{abstract}

${ }^{2}$ Private agricultural advisor. Apaseo el Grande, 114, Col Guanajuato, Celaya,

Guanajuato, Mexico. CP 38010.

KEY WORDS: Organic matter, moisture, minerals, biostability and substrate respiration.

\section{ABSTRACT}

The objective was to evaluate the mineralization of two mixtures of substrates with different nitrogen content, moisture, compost and mineral mixture based on zeolite and dolomite. The measured parameters were $\mathrm{pH}$ (extract 1:2), electrical conductivity (extract 1:5) by conductimeter; content of organic matter by ignition; organic carbon based on the results of organic matter using the Douglas factor= 0.5; and nitrogen per micro Kjeldahl. The flow of $\mathrm{CO} 2$ was measured with the IRGA gas analyzer. For both moisture content, the compost-free substrates had a higher $\mathrm{C} / \mathrm{N}$ ratio. Compost substrates, because of their high mineralization, were appropriate with advantages to the supply of nitrogen. Substrates with compost and 15\% moisture released higher CO2 by presenting more easily degradable compounds. Mineralization rates on substrates were higher with $15 \%$ humidity due to increased porous space occupied by gases, in addition, the supply of $50 \%$ of nitrogen had a low immobilization due to the lower organic matter content and the $40 \mathrm{~cm} 3 \mathrm{~L}-1$ mineral mixture content changed the dilution of carbon to be metabolized by microorganisms. The rate of mineralization was affected by the use of minerals, the quality and the subtrate origin.

\section{EVALUACIÓN DE MINERALIZACIÓN DE SUSTRATOS POR FLUJO DE C-CO2 BAJO FERTILIZACIÓN DE NITRÓGENO}

\section{PALABRAS CLAVES}

Materia orgánica, humedad, minerales, bioestabilidad y respiración del sustrato.

SUELOS ECUATORIALES 49 (1 y 2$): 19-28$

ISSN 0562-5351 e-ISSN 2665-6558

\section{RESUMEN}

El objetivo fue evaluar la mineralización de dos mezclas de sustratos con diferente contenido de nitrógeno, humedad, compost y mezcla mineral a base de zeolita y dolomita. Los parámetros medidos fueron pH (extracto 1: 2), conductividad eléctrica (extracto 1: 5) por conductímetro; contenido de materia orgánica por ignición; carbono orgánico basado en los resultados de la materia orgánica usando el factor Douglas = 0.5; y nitrógeno por micro Kjeldahl. El flujo de CO2 se midió con el analizador de gases IRGA. Para ambos contenidos de humedad, los sustratos sin compost tenían una relación C/N más alta. Los sustratos de compost, debido a su alta mineralización un $15 \%$ de humedad debido al aumento del espacio poroso ocupado por los gases, además, el suministro de $50 \%$ de nitrógeno tuvo una baja inmovilización debido al menor contenido de materia orgánica y al contenido de la mezcla mineral L-1 de $40 \mathrm{~cm} 3$ cambió la dilución de carbono para ser metabolizada por microorganismos. La tasa de mineralización se vio afectada por el uso de minerales, la calidad y el origen del sustrato. 


\section{INTRODUCTION}

Currently, fertilization management techniques and crop production are required to prevent, as far as possible, soil degradation and environmental pollution problems (Martín y Rivera, 2004). One procedure is by replacing soil cultivation with substrate cultivation (Abad y Noguera, 1997). When assessing the quality of a substrate, account must be taken of the proportion of the organic fraction since it is an essential constituent, due its properties and constitution, is responsable for most physicochemical and biological processes (Aguilera et al., 1999), especially in total nitrogen content. Nutrientes present in organic matter transforms into inorganic forms, which are available to plants (Guerrero-Ortiz et al., 2012), this process is known as mineralization (Steubing et al., 2001) and causes the reduction of the organic fraction during the conversion of nutrients and the $\mathrm{CO} 2$ release that are incorporated into plants, atmosphere and waste from organic complexes (Chapin et al., 2011). The flow of CO2 its a parameter tied with the potential fertility both soil and substrate.

While a mineral fraction present improves physical conditions by increasing aeration capacity (Gutiérrez-Castorena et al., 2011), which increases moisture retention capacity and promotes the process of decomposing the organic labile fraction (Wilhelm et al., 2004). The use of minerals, such as zeolite, in substrate has not been developed on a large scale (Stamatakis et al., 2001), in Mexico the use of this resource has received little attention; while in other countries it has been widely used for use as a substrate in hydroponic cultures (Steinberg et al., 2000; Stamatakis et al., 2001 y Ostroumov et al., 2005). While the use of dolomite in agriculture has shown that it influences $\mathrm{pH}$ correction and nutrient supply as well $\mathrm{Ca}$ and $\mathrm{Mg}$ (Corpoica, 2005).

The objective of the experiment was to evaluate the CO2 flow of two mixtures of substrates with different nitrogen content, moisture, compost and mineral mixture based on zeolite and dolomite to know the effect to the substrates mineralization.

\section{MATERIALS AND METHODS}

The essay was carried out in the Soil Physics Laboratory at Montecillo Campus Colegio de Postgraduados in the State of Mexico, Mexico. Two mixtures of substrates were used: 1) tezontle and sawdust (1:2) and 2) tezontle, sawdust and compost $(1: 2: 2)$, both with different mineral mixture contents of zeolite and dolomite $(0,40$ and $80 \mathrm{~cm} 3 \mathrm{~L}-1)$. Two referenced nitrogen concentrations (50 and 100\%) were supplied by the Universal Steiner Solution, in addition to two levels of humidity (15 and $30 \%$ dry weigth basis) resulting in 24 treatments with 3 repetitions. The samples were incubated for 15 days to promote microbial activity and evaluate, each 48 hours, the $\mathrm{CO} 2$ flow for 86 days with support of the IRGA gas analyzer (PP Systems); the samples were moistened based on its dry weight every 7 days until the end of the trial. The measured parameters were $\mathrm{pH}$ (extract 1:2), electrical conductivity (extract 1:5) by conductimeter; content of organic matter by ignition; organic carbon based on the results of organic matter using the Douglas factor $=0.5$; and nitrogen per micro Kjeldahl. The analysis of the variables was performed using a completely randomized design and the means tests by comparing Tukey with a value of statistical significance $p \leq 0.05$.

\section{RESULTS AND DISCUSSION}

\section{Chemical characteristics of substrates}

$\mathrm{pH}$. - Fort he two humidity levels, the most alkaline $\mathrm{pH}$ value was obtained by $\mathrm{T} 9$ (7.74 and 7.89$)$ while $\mathrm{T} 1$ showed the most acidic $\mathrm{pH}$ (6.04) with $15 \%$ humidity and, with $30 \%$ humidity, $\mathrm{T} 5$ showed a pH of 6.80. The absolute mineralization rate (AMR) of $\mathrm{T} 9$, although it presented significant statistical differences, was only $0.06 \mathrm{~g} \mathrm{CO} 2 / \mathrm{g}$ susbtrate/day higher due to the effect of $\mathrm{pH}$. On the other hand, the AMR was $21 \%$ higher when the $\mathrm{pH}$ varied 0.21 units between T1 and T5. In most treatments, pH was kept within desirable ranges for substrate production (5.0 
-6.5; Bunt, 1998), changes of $0.15 \mathrm{pH}$ units between humidity levels and mineral mixture content occur because, in the exchange complex, the $\mathrm{Ca}$ of the dolomite replacement of $\mathrm{H}+$ ions, in addition to the ammonia detachment of organic labile materials (compost) (Soliba, 1998) causing an increase in $\mathrm{pH}$ of substrat extract. Alvarado y Fallas (2004) they mention the dolomite as an alternative to reduce acidity.

Electrical conductivity. - Although the EC results obtained did not exceed the recommended ranges for the production of crops in substrates $(0-1.15 \mathrm{dS}$ $\mathrm{m}-1$; Bunt, 1998), the treatments containing compost the EC was higher compared to those that did not contain compost. With a difference of $0.99 \mathrm{dS} \mathrm{m}-1$, treatments containing compost had average AMR of $1.24 \mathrm{~g} \mathrm{CO} / \mathrm{g}$ susbtrate/day; while the AMR of treatments without compost, and lower EC, was 0.82 g CO2/g susbtrate/day. In those treatments where the EC was $>2 \mathrm{dS} \mathrm{m}-1$ is attributed to the high decomposition of organic labile materials ( $R 2=0.82$ ), in addition, Rodríguez et al., (2010) mention that the concentration of salts grows by the loss of mass of the substrates, the product of the mineralization of the OM.

Total nitrogen. - The highest content of nitrogen, for both humidity levels, It was presented by T7 (1.83 and $1.99 \%$ ), to which $50 \%$ of $\mathrm{N}$ was supplied, being statistically different from other treatments. While the $\mathrm{T} 7 \mathrm{got}$ the highest content of $\mathrm{N}$ was not triggering to achieve the highest AMR, with $1 \mathrm{~g} \mathrm{CO} / \mathrm{g}$ susbtrate/day being less than the T8 which obtained the highest AMR ( $1.96 \mathrm{~g} \mathrm{CO} / \mathrm{g}$ susbtrate/day) by the effect of supplying $\mathrm{N}$. The low values of total $\mathrm{N}$ are related to a high $\mathrm{C} / \mathrm{N}$ ratio $(\mathrm{R} 2=0.89)$ the product of the higher content of non-labile organic materials (sawdust), therefore, the substrates of these treatments showed greater stability and a slow process of mineralization. The use of zeolite, a chemically very active clay, caused the $\mathrm{N}$ mineralization process to be slow by competition in microorganisms and the porous mineral, causing a synchronisation between the nourishment absorbed by the plant and the one supplied (Febles et al., 2014). 
Table 1. Test of means of the chemical properties of the substrates with 15 and $30 \%$ moisture.

\begin{tabular}{|c|c|c|c|c|c|c|c|c|c|c|c|c|}
\hline \multirow{3}{*}{ Treatment } & \multicolumn{6}{|c|}{$15 \% \mathrm{~h}$} & \multicolumn{6}{|c|}{$30 \% \mathrm{~h}$} \\
\hline & \multirow{2}{*}{ pH } & \multirow{2}{*}{$\begin{array}{c}\mathrm{EC} \\
\left(\mathrm{dS} \mathrm{m^{-1 }}\right)\end{array}$} & $\mathbf{N}$ & OC & OM & \multirow{2}{*}{$\mathrm{C} / \mathrm{N}$} & \multirow{2}{*}{ pH } & \multirow{2}{*}{$\begin{array}{c}\mathrm{EC} \\
\left(\mathrm{dS} \mathrm{m}^{-1}\right)\end{array}$} & \multirow[t]{2}{*}{$\mathbf{N}$} & OC & \multirow[t]{2}{*}{$\mathbf{O M}$} & \multirow{2}{*}{$\mathrm{C} / \mathbf{N}$} \\
\hline & & & & $(\%)$ & & & & & & $(\%)$ & & \\
\hline 1 & $6.04 \mathrm{~d}$ & $0.91 \mathrm{e}$ & $0.192 \mathrm{~d}$ & $15.66 \mathrm{a}$ & $31.66 \mathrm{a}$ & $82.5 \mathrm{e}$ & $6.87 \mathrm{c}$ & $1.07 \mathrm{~d}$ & $0.087 \mathrm{c}$ & $17.00 \mathrm{a}$ & $34.66 \mathrm{a}$ & $196.5 \mathrm{a}$ \\
\hline 2 & $7.00 \mathrm{~b}$ & $1.05 \mathrm{~d}$ & $0.175 \mathrm{~d}$ & $19.00 \mathrm{a}$ & $37.33 \mathrm{a}$ & $106.5 \mathrm{c}$ & $7.14 \mathrm{~b}$ & $1.03 \mathrm{~d}$ & $0.175 \mathrm{c}$ & $12.33 \mathrm{a}$ & $25.00 \mathrm{a}$ & $71.5 \mathrm{e}$ \\
\hline 3 & $7.36 \mathrm{a}$ & $0.99 \mathrm{e}$ & $0.122 \mathrm{~d}$ & $11.33 \mathrm{~b}$ & $23.00 \mathrm{~b}$ & $93.5 \mathrm{~d}$ & $7.41 \mathrm{~b}$ & $1.06 \mathrm{~d}$ & $0.140 \mathrm{c}$ & $14.33 \mathrm{a}$ & $29.33 \mathrm{a}$ & $103.5 \mathrm{c}$ \\
\hline 4 & $7.04 \mathrm{~b}$ & $0.66 \mathrm{e}$ & $0.157 \mathrm{~d}$ & $17.66 \mathrm{a}$ & $35.33 \mathrm{a}$ & $110.5 \mathrm{~b}$ & $7.15 \mathrm{~b}$ & $0.76 \mathrm{e}$ & $0.105 \mathrm{c}$ & $18.33 \mathrm{a}$ & $36.00 \mathrm{a}$ & $170.5 \mathrm{~b}$ \\
\hline 5 & $6.21 \mathrm{c}$ & $0.82 \mathrm{e}$ & $0.227 \mathrm{~d}$ & $13.00 \mathrm{~b}$ & $26.66 \mathrm{a}$ & $57.5 \mathrm{f}$ & $6.80 \mathrm{c}$ & $0.97 \mathrm{~d}$ & $0.227 \mathrm{c}$ & $13.33 \mathrm{a}$ & $26.66 \mathrm{a}$ & $59.5 \mathrm{f}$ \\
\hline 6 & $6.61 \mathrm{c}$ & $0.65 \mathrm{e}$ & $0.140 \mathrm{~d}$ & $12.00 \mathrm{~b}$ & $24.00 \mathrm{~b}$ & $114.5 \mathrm{a}$ & $7.09 \mathrm{~b}$ & $0.92 \mathrm{~d}$ & $0.140 \mathrm{c}$ & $11.00 \mathrm{a}$ & $22.33 \mathrm{a}$ & $78.5 \mathrm{~d}$ \\
\hline 7 & $6.96 \mathrm{~b}$ & $1.31 \mathrm{~d}$ & $1.837 \mathrm{a}$ & $13.33 \mathrm{a}$ & $28.33 \mathrm{a}$ & $7.5 \mathrm{~g}$ & $7.28 \mathrm{~b}$ & $1.49 \mathrm{c}$ & $1.995 \mathrm{a}$ & $12.33 \mathrm{a}$ & $24.00 \mathrm{a}$ & $6.5 \mathrm{~h}$ \\
\hline 8 & $6.71 \mathrm{~b}$ & $2.12 \mathrm{~b}$ & $1.592 \mathrm{~b}$ & $10.66 \mathrm{~b}$ & $21.33 \mathrm{~b}$ & $8.0 \mathrm{~g}$ & $7.02 \mathrm{~b}$ & $1.90 \mathrm{a}$ & $1.470 \mathrm{~b}$ & $11.33 \mathrm{a}$ & $23.00 \mathrm{a}$ & $8.5 \mathrm{~g}$ \\
\hline 9 & $7.74 \mathrm{a}$ & $2.21 \mathrm{~b}$ & $1.137 \mathrm{c}$ & $8.66 \mathrm{~b}$ & $17.33 \mathrm{~b}$ & $7.0 \mathrm{~h}$ & $7.89 \mathrm{a}$ & $1.65 \mathrm{~b}$ & $1.540 \mathrm{~b}$ & $10.66 \mathrm{a}$ & $21.33 \mathrm{a}$ & $6.5 \mathrm{~h}$ \\
\hline 10 & $7.47 \mathrm{a}$ & $1.67 \mathrm{c}$ & $1.330 \mathrm{c}$ & $14.66 \mathrm{a}$ & $28.33 \mathrm{a}$ & $10.5 \mathrm{~g}$ & $7.38 \mathrm{~b}$ & $2.15 \mathrm{a}$ & $1.610 \mathrm{~b}$ & $14.00 \mathrm{a}$ & $27.66 \mathrm{a}$ & $10.5 \mathrm{~g}$ \\
\hline 11 & $7.61 \mathrm{a}$ & $1.54 \mathrm{c}$ & $1.225 \mathrm{c}$ & $11.33 \mathrm{~b}$ & $22.66 \mathrm{~b}$ & $9.5 \mathrm{~g}$ & $7.38 \mathrm{~b}$ & $2.06 \mathrm{a}$ & $1.890 \mathrm{a}$ & $13.00 \mathrm{a}$ & $25.66 \mathrm{a}$ & $7.5 \mathrm{~h}$ \\
\hline 12 & $6.90 \mathrm{~b}$ & $2.86 \mathrm{a}$ & $1.540 \mathrm{~b}$ & $11.66 \mathrm{~b}$ & $23.33 \mathrm{~b}$ & $7.5 \mathrm{~h}$ & $7.40 \mathrm{~b}$ & $1.82 \mathrm{~b}$ & $1.347 \mathrm{~b}$ & $12.00 \mathrm{a}$ & $23.66 \mathrm{a}$ & $8.5 \mathrm{~g}$ \\
\hline LSD $(p \leq 0.05)$ & 0.54 & 0.46 & 0.239 & 5.94 & 11.50 & 3.03 & 0.29 & 0.31 & 0.264 & 10.42 & 20.26 & 2.80 \\
\hline
\end{tabular}

Where: pH. - Hydrogen potential, EC. - Electrical conductivity, N.- Total nitrogen, OC.- Organic carbon, OC. - Organic matter, C/N.- C/N ratio and h.- Humidity. LSD (p $\leq 0.05)$. Low stadistical diference with a statistical probability of $5 \%$. Treatments with diferents letters have different statistical significance $(p \leq 0.05)$. 
Organic matter. - Usually, the treatments with compost showed the lowest OM content result of greater mineralization. The relative rate of mineralization (RRM) showed a difference of $68 \%$ mineralization between T8 (1.96 g CO2/g susbtrate/day) with compost and T6 (0.626 g CO2/g susbtrate/day) without compost. OM values found in those treatments that contained mineral mixture it is attributed, according to Rodríguez et al., (2010) to the addition and/or presence of non-combustible materials in incineration and organic materials rich in lignins.

Organic carbon. - The treatments with 15\% moisture showed significant statistical differences at the OC content T9 being the lowest with $8.66 \%$ and T12, with $19 \%$. For both moisture content, and with an average difference of $14.16 \%$ OC, the RRM was $0.17 \mathrm{~g} \mathrm{CO} / \mathrm{g}$ susbtrate/day per effect of the OC content. Substrates with compost, containing higher $\mathrm{OC}$, they corresponded; according to $\mathrm{T}$ to a high mineralization resulting from the higher availability of labile carbon of the OM.

$\mathrm{C} / \mathrm{N}$ ratio. - In both moisture levels, treatments without compost showed the highest $\mathrm{C} / \mathrm{N}$ ratio with values 57.5 - 196.5, while treatments with compost showed de lowest values $(<10.5)$. The treatments RRM with compost, and a low $\mathrm{C} / \mathrm{N}$ ratio, was $1.34 \mathrm{~g}$ $\mathrm{CO} 2 / \mathrm{g}$ susbtrate/day higher compared to those treatments without compost and high $\mathrm{C} / \mathrm{N}$ ratio. Substrates $\mathrm{C} / \mathrm{N}$ ratio from 5 to 20 indicates that they are mature (Terés, 2001) and offer greater

a)

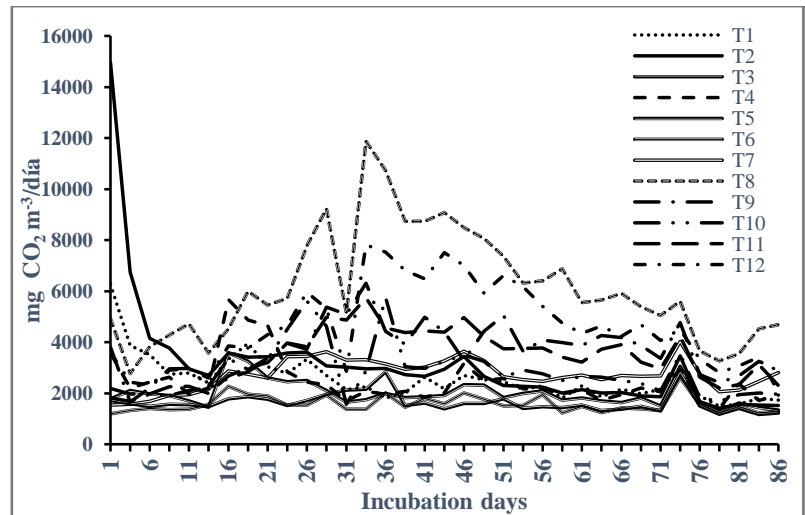

inorganically available nutrients, treatments that did not contain compost were $\mathrm{C} / \mathrm{N}$ ratio $>57$ due to the increased presence of materials which were not decomposed (Lemaire, 1997) because they have high lignin content, susbtrates of these treatments are the most appropriate for the production of longcycle crops.

CO2 flow in substrates with different moisture content

During the first 7 days of incubation and under 15 humidity, $\mathrm{CO} 2$ exhibited variations, mainly in treatments that did not contain compost. The maximum values of $\mathrm{CO} 2$ were presented from days 33 to 36 , obtaining the highest emission of T8 and T12 with 11,871 and $7,911 \mathrm{mg} \mathrm{CO} 2 \mathrm{~m}-3 /$ day, respectively. After 14 days of incubation, and when the substrates contained $30 \%$ moisture, the detached $\mathrm{CO} 2$ was higher in treatments containing compost. The maximum values of $\mathrm{CO} 2$ were presented from days 26 to 38 , obtaining the highest emission of T8 $(9,245 \mathrm{mg} \mathrm{CO} 2 \mathrm{~m}-3 /$ day) and T9 (6,435 mg CO2 m-3/day).

The rate of $\mathrm{CO} 2$ emissions for substrates with compost and under the two humidity levels, it relates to Velasco and De Mingo (1981) who point out that mineralization is approximately $80 \%$ higher in media containing easily degrading OM. In substrates containing sawdust, the organic fraction is stable because labile material is available in a smaller proportion, which slows the degradation of $\mathrm{OM}$ (Acosta et al., 2006).

b)

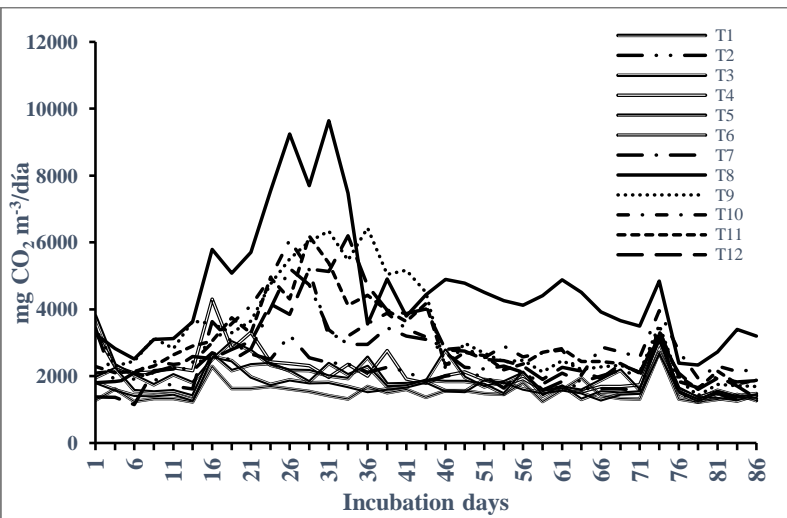

Figure 1. a) $\mathrm{CO} 2$ evolution in substrates with $15 \%$ moisture and b) $\mathrm{CO} 2$ evolution in subtrates with $30 \%$ moisture, both in 86 incubation days. 
CO2 accumulatiive in substrates with different moisture content

T8 and T12, with $15 \%$ moisture, desped out major CO2 after 30 days of incubation $(99,253$ y $69,678 \mathrm{mg}$ $\mathrm{CO} 2 / \mathrm{g}$ substrate, respectively) by the presence of compost. With $30 \%$ moisture content, the treatments that got the greatest accumulation of $\mathrm{CO} 2$ at the end of the experiment were T8 with $82,373 \mathrm{mg} \mathrm{CO} 2 / \mathrm{g}$ substrate and T9 $(59,773 \mathrm{mg}$ CO2/g substrate). The tended to release higher $\mathrm{CO} 2$ when the humidity present is lower is attributed to the smaller space occupied by total porous space (Or and Weaight, 2000) because the substrates increase their capacity for gravimetric moisture retention by increasing the percentage of total porosity. The content of moisture 15 and $30 \%$, in both susbtrate mixture, caused detachment of concentrations greater than 2,000 ppm of CO2/day. Lorenzo (2012) mentions that to achieve the highest photosynthetic rate in pepper cultivation you should have a concentration of 1,000 ppm, which is commonly applied by $\mathrm{CO} 2$ injectors being an expensive method (Antón et al., 2011). a)

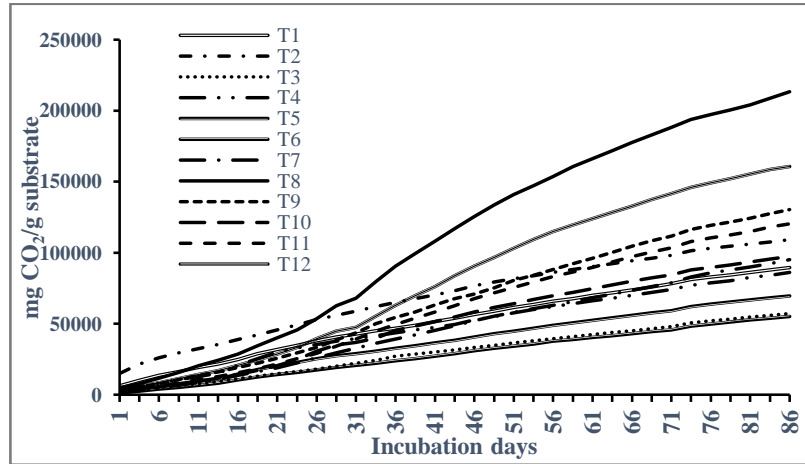

b)

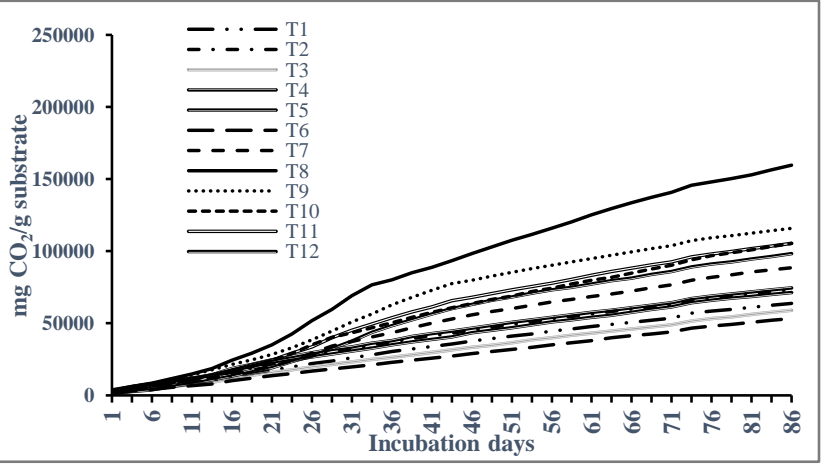

Figure 4. a) $\mathrm{CO} 2$ accumulation in substrates with 15\% moisture and b) $\mathrm{CO} 2$ accumulation in subtrates with $30 \%$ moisture, both in 86 incubation days.

\section{Absolute and relative mineralization rate}

AMR fluctuation of substrates con $15 \%$ moisture was $0.63 \mathrm{~g} \mathrm{CO} 2 / \mathrm{g}$ substrate/day in the T6 and $2.24 \mathrm{~g}$ $\mathrm{CO} 2 / \mathrm{g}$ substrate/day at T8. With regard to the substrate with $30 \%$ moisture, the AMR followed the same trend as with the $15 \%$ moisture, T6 showed the AMR lowest with $0.61 \mathrm{~g} \mathrm{CO} / \mathrm{g}$ substrate/day and T8 the higher AMR with $1.68 \mathrm{~g} \mathrm{CO} / \mathrm{g}$ substrate/day. Occupied moisture is easily released by the presence of macropores and packaging pores (Hillel, 1998), so in treatments with higher moisture content porous space was smaller and therefore the amount of $\mathrm{CO} 2$ released was smaller.
AMR of treatments 7 to 12, with compost, showed the highest $\mathrm{CO} 2$ flow for both $\mathrm{N}$ levels with fluctuations of 0.96 to $1.96 \mathrm{~g} \mathrm{CO} 2 / \mathrm{g}$ substrate/day. In treatments with the supply of $50 \% \mathrm{~N}$ values with the highest emission range (0.66 to $1.96 \mathrm{~g} \mathrm{CO} / \mathrm{g}$ substrate/day), while in those that were supplied the $100 \%$ of $\mathrm{N}$ that range decreased by a $50 \%$. When the content of $\mathrm{N}$ was $100 \%$ there was biotic immobilization of the nutrient, Ritter et al., (2005) mentions that microorganisms immobilize $\mathrm{N}$ for consumption in conjunction with $\mathrm{OM} \mathrm{N-NH4+}$ reaction and clay fraction composed by zeolite. 
a)

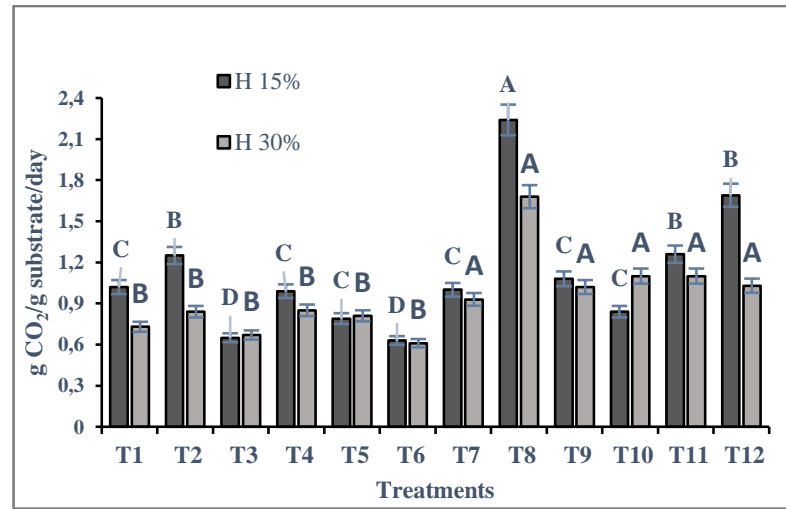

c) b)

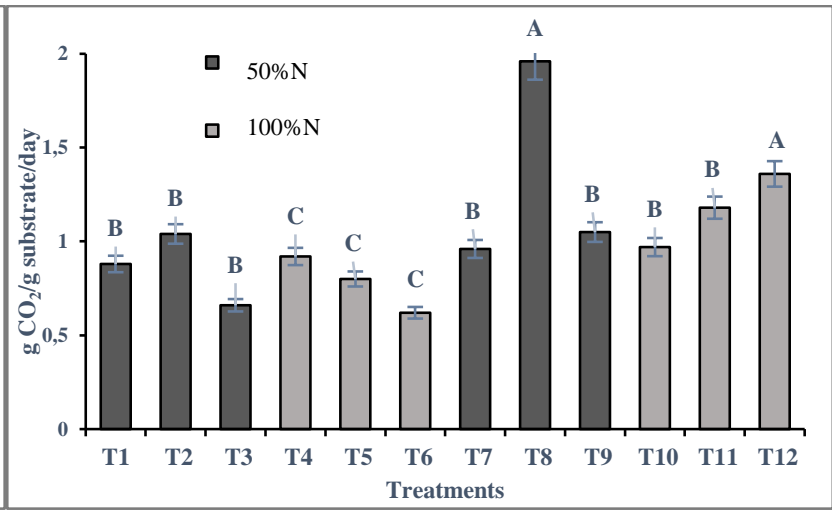

d)

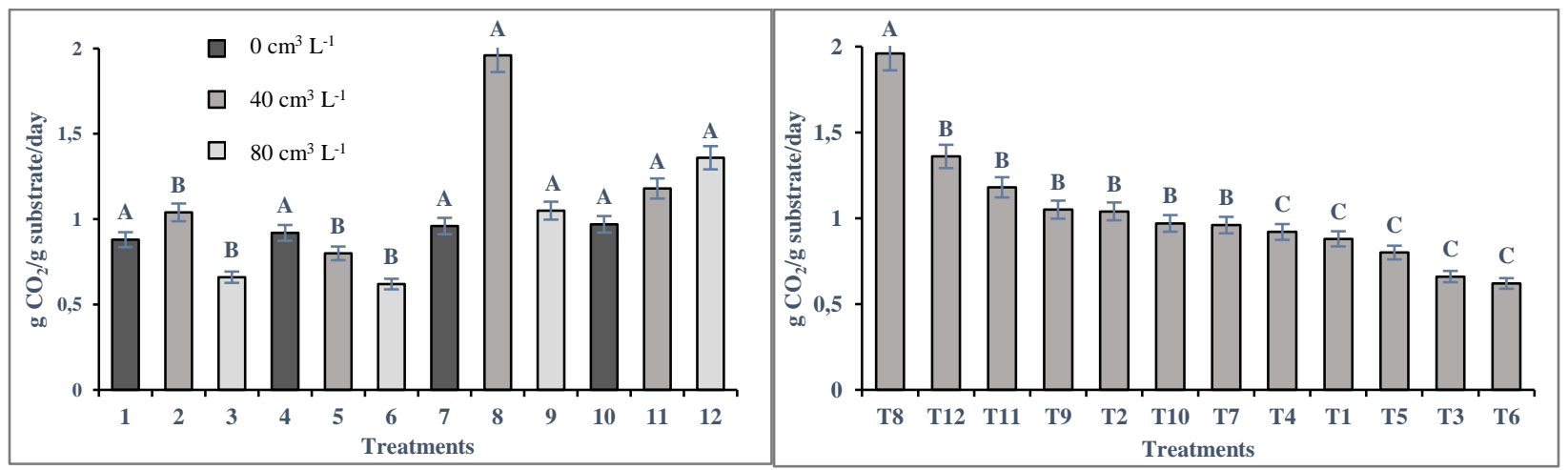

Figure 5. a) Absolute rate of mineralization of substrates with two moisture levels, b) Absolute rate of mineralization of substrates with two nitrogen levels, c) Absolute rate of mineralization of substrates with three mineral mixture levels and d) Relative rate of mineralization of the substrates; at 86 incubation days.

In T2, T5, T8 and T11, treatments with $40 \mathrm{~cm} 3$ of MM L-1 of substrate, the largest AMR was observed with values ranging from 0.80 to $1.96 \mathrm{~g} \mathrm{CO} 2 / \mathrm{g}$ substrate/day. When compost was applied and 80 cm3 L-1 MM content (T9 and T12), an average AMR of $1.20 \mathrm{~g} \mathrm{CO} 2 / \mathrm{g}$ substrate/day was presented, when compost it was not applied emissions reduced by a $39 \%$ with the same MM content. In this regard it has been found, Scott et al., (1996), mineralization to occur in a stable manner they must first be waste should be metabolized by microbial action and then stabilized by mineral colloids. Treatments with 80 cm3 L-1 of MM with the presence of compost presented a dilution effect of $\mathrm{C}$ with the clay fraction, which means that $\mathrm{OM}$ is evenly distributed in the mineral matrix (Matus et al., 1998).
It was observed that the T presented the highest AMR with $1.96 \mathrm{~g} \mathrm{CO} / \mathrm{g}$ substrate/day due to compost content, beating $0.60 \mathrm{~g} \mathrm{CO} / \mathrm{g}$ substrate/day of $\mathrm{T} 12$. The higher content of high $\mathrm{C} / \mathrm{N}$ ratio in T6 was reflected to emit $1.34 \mathrm{~g} \mathrm{CO} 2 \mathrm{~g}$ substrate/day less that T8, which caused $T 6$ to be treated with the lowest AMR. According to Acosta et al., (2006), biological activity is very active by the presence of labile organic materials, that means that when $\mathrm{CO} 2$ emission is increased by use of compost, more $C$ is released into environment and reduced depending on the amount of minerals supplied.

\section{CONCLUSIONS}

In substrates it does not follow the logic that the higher moisture is present in the soil, the greater the 
mineralization of organic matter. Using compost-free substrates, $80 \mathrm{~cm} 3$ of mineral mixture L-1 of substrate and $15 \%$ humidity delayed the mineralization of organic matter and the $\mathrm{CO} 2$ flow emitted was lower, showing favorable emissions for plant utilization and increased photosynthetic rate, which complements the contribution of $\mathrm{CO} 2$ to intensive production systems. Substrates with compost and $15 \%$ humidity they delayed their initial

\section{REFERENCES}

Abad, M. y P. Noguera. 1997. Los sustratos en los cultivos sin suelo. pp. 101-150. In: Manual de cultivo sin suelo. M. Urrestarazu (ed.). Universidad de Almería. Servicio de Publicaciones.

Acosta, Y., J. Cayama, E. Gómez, N. Reyes, D. Rojas y H. García. 2006. Respiración microbiana y prueba de fitotoxicidad en el proceso de compostaje de una mezcla de residuos orgánicos. Multiciencias 6: $220-227$.

Aguilera, S.M., Borie, G., Peirano, P. 1999. Dinámica del carbono en suelos con distintos sistemas de labranza. Frontera Agrícola Vol. 5 № 1-2: p 33-38.

Alvarado, A. y Fallas, J. 2004. La saturación de acidez y el encalado sobre el crecimiento de la teca (Tectona Grandis I.F.) en suelos ácidos de Costa Rica.

Ansorena, M., 1994. Sustratos propiedades y caracterización. Mundi-Prensa. Madrid, España.

Antón, A.; Aranda, X.; Biel, C.; Herralde, F.; Montero, J.; Montero, J. I.; Morales, C; Muñoz, P.; Savé, R. 2011. Manual del Aplicador de $\mathrm{CO} 2$ en Cultivos Hortícolas. IRTA. 34 p.

Bunt A. C. 1988. Media and Mixes for ContainerGrow Plants. Unwin Hyman. Londres, RU. 77 pp.

Chapin III F. S., Matson P. A. y Vitousek P. 2011. Principles of terrestrial ecosystem ecology. Springer Science \& Business Media.

Corpoica V. 2005. Efectos de la aplicación de cal dolomítica y yeso agrícola en cafetales (Coffea mineralization, but also led to greater $\mathrm{CO} 2$ liberation and an increase in the chemical fertility of the substrate.

\section{ACKNOWLEDGEMENTS}

To the National Council of Science and Technology (CONACYT) for funding for the implementation of this research.

arabica) afectados con Mal de Viñas en Guatemala. Manejo Integrado de Plagas y Agroecología. Costa Rica. 76 p.

Douglas W. P. 2010. A critical review of the conventional SOC to SOM conversion factor. Geoderma. 156: 75-83.

Febles J., Borsatto F. and Soca M. 2014. FercelClinoptilolite natural product to optimize the fertilizatión and reduce enviromental pollution. p 156160. In: Memorias 16th World Fertilizer Congress of CIEC. Technological Innovation for a Sustaintable Tropical Agriculture. Río de Janeiro, Brasil.

Guerrero-Ortiz, P.L., Quintero-Lizaola, R., EspinozaHernández, V., Benedicto-Valdés, G.S. y SánchezColín, M.J. 2012. Respiración de CO2 como indicador de la actividad microbiana en abonos orgánicos de Lupinus. Terra Latinoamericana 30 (4): 355-362.

Gutiérrez-Castorena, M. C., Hernández-Escobar J., Ortiz-Solorio C. A., Anicua-Sánchez R. y HernándezLara M. E. 2001. Relación porosidad-retención de humedad en mezclas de sustratos y su efecto sobre variables respuesta en plántulas de lechuga. Rev. Chapingo Serie Horticultura. 17(3): 183-196.

Hiller, D. 1998. Environmental Soil Physics. Academic Press. San Diego, C.A. 771 pp.

Lemaire F. 1997. The problem of bioestability in organic susbtrates. Acta Hort. 450: 63-69.

Lorenzo, P. 2012. El Cultivo en Invernadero y su Relación con el Clima. En Innovación en Estructuras 
Productivas y Manejo de Cultivos en Agricultura Protegida. J. C.

Martín, G.M. y Rivera, R. 2004. Mineralización del nitrógeno incorporado con abonos verdes y su participación en la nutrición de cultivos de importancia económica. Cultivos Tropicales, vol. 25, núm. 3, pp. 89-96.

Matus, F. J.; Maire, C. and Villalobos, M. P. 1998. Interaction between soil texture and organic matter of clay and silt particles from arable and non-arable soils. $16^{\circ}$ World Congress of Soil Science. Montpellier, France. 1-24 agost. Symposia № 4. p. 110.

Norma Oficial Mexicana. NOM-021-RECNAT-2000. Que establece las especificaciones de fertilidad, salinidad y clasificación de suelos. Estudios, muestreo y análisis.

Or, D.; Weaight, J. M. 2000. Soil water content and water potentional relationships. A-53 - A83 pp. In Handbook of soil Science. SUMMER, M.E. (ed). CRC press. Wastington, D.C.

Ostroumov, M. F., H. Ortiz y C. P. Corona. 2005. Zeolitas de México: Diversidad mineralógica y aplicaciones. http://smm.iim.umich.mx/zeolitas.htm (Consulta: enero 25, 2019).

Pérez B., P., G. Ouro, A. Merino y F. Macías. 2009. Descomposición de materia orgánica, biomasa microbiana y emisión de $\mathrm{CO} 2$ en un suelo forestal bajo diferentes manejos sevícolas. Edafología 5: 8393.

Ritter E., M. Starr and L. Vesterdal. 2005. Losses of nitrate from gaps of different sizes in a managed beech (Fagus sylvatica) forest. Canadian Journal of Forest Research 35: 308-319.

Rodríguez Macías, Ramón, Alcantar González, Ernesto G., Iñiguez Covarrubias, Gilberto, Zamora Natera, Francisco, García López, Pedro M., Ruiz López, Mario A., Salcedo Pérez, Eduardo. 2010. Caracterización física y química de sustratos agrícolas a partir de bagazo de agave tequilero. Interciencia, 35.

Scott, N.; Cole, C.; Elliott, E.T. and Huffman, S. 1996. Soil textural control on decomposition and soil organic matter dynamics. Soil Sci. Soc. Am. J. 60: 11021109.

Soliba M. 1998. Aplicación del compostaje a la obtención de productos alternativos a los sustratos tradicionales. En Pastor S, J Narciso (eds) Tecnología de Sustratos. Aplicación a la Producción Viverística Ornamental, Hortícola y Forestal. Universidad de Leida, España. pp. 51-65.

Stamatakis, M.G., N. Koukouzas, C. Vassilatos, E, Kamenou, and K. Samantouros. 2001. The zeolites from Evros region, Northern Greece: A potential use as cultivation substrate in hydroponics. Acta Hortic. 548: 93-103.

Steinberg, S. L., D. W. Ming, K. E. Henderson, C. Carrier, J. E. Gruener, D. J. Barta, and D. L. Henninger. 2000. Wheat response to differences in water and nutritional status between zeoponic and hydroponic growth systems. Agron. J. 92: 353-360.

Steubing, L., R. Godoy y M. Alberdi. 2001. Métodos de ecología vegetal. Universitaria. Santiago, Chile.

Terés T., V. 2001. Relaciones aire agua en sustratos de cultivo como base para el control de riego. Metodología de laboratorio y modelización. Tesis doctoral, Universidad Politécnica de Madrid. Madrid: Escuela Técnica Superior de Ingenieros Agrónomos. 483p.

Tiquia S.M., Richard T.L. y Honeyman M.S. 2002. Carbon, nutrient, and mass loss during composting. Nutr. Cycl. Agroecosys. 62, 15-24.

Velasco F. and De Mingo P. 1981. Distribución de la materia orgánica libre y ligada, y de las fracciones de humina en suelos climácicos y en suelos degradados. An Edafol Agrobiol 40, 179-190. 
Walkley, A. and I. A. Black. 1934. An examination of the Degtjareff method for determining soil organic matter and a proposed modification of the chromic acid titration method. Soil Sci. 37: 29-38.

Wilhelm W.W., Johnson J.M.F., Hatfield J.L., Voorhees W.B., Linden D.R. 2004. Crop and soil productivity response to corn residue removal: a literature review. Agron. J. 96: 117. 